\title{
Skill mapping of production workforce in small scale knitwear units of Ludhiana
}

\author{
AMANPREET KAUR, SURABHI MAHAJAN AND HARMINDER SAINI
}

Received: 22.02.2017; Revised: 18.04.2017; Accepted: 04.05.2017

See end of the paper for authors' affiliations

\section{AMANPREET KAUR}

Department of Apparel and Textile Science, College of Home Science,

Punjab Agricultural University, LUDHIANA (PUNJAB) INDIA
ABSTRACT : The Indian Knitwear industry has an overwhelming contribution in the GDP of the country. Small firms are an important source of employment in India and employ a sizable share of the labour force. Ludhiana Knitwear Industry is very versatile and is manufacturing various types of products. The production workforce plays an important role in determining the quality and quantity of products being made hence, the present research is focused to find out the existing skill sets and skill gaps in production workforce of ten small scale knitwear units of Ludhiana. Data collected from 150 respondents reveal that the production labour was uneducated and lacked vocational qualification, machine knowledge and self understanding of the work. The skill gaps existed in areas pertaining to qualification, efficiency and machine knowledge.

KEY WORDS: GDP, Knitwear, Production workforce, Skill sets

- HOW TO CITE THIS PAPER : Kaur, Amanpreet, Mahajan, Surabhi and Saini, Harminder (2017). Skill mapping of production workforce in small scale knitwear units of Ludhiana. Asian J. Home Sci., 12 (1) : 170-174, DOI: 10.15740/HAS/AJHS/12.1/170-174. 